\title{
The Determinants of Forward-Looking Information in Management Commentary: Evidence from Italian Listed Companies
}

\author{
Elisa Menicucci ${ }^{1}$ \\ ${ }^{1}$ Department of Management, Polytechnic University of Marche, Ancona, Italy \\ Correspondence: Elisa Menicucci, Department of Management, Polytechnic University of Marche, Ancona, Italy. \\ Tel: 39-71-220-7186. E-mail: e.menicucci@univpm.it
}

Received: March 21, 2013

Accepted: April 2, 2013

Online Published: April 17, 2013

doi:10.5539/ibr.v6n5p30

URL: http://dx.doi.org/10.5539/ibr.v6n5p30

\begin{abstract}
The aim of this paper is to assess the level of forward-looking information in Management Commentaries of Italian listed companies and to empirically explore the firm characteristics that may affect the extent of forward-looking information disclosed. A disclosure index composition consisting of 15 forward-looking information items is developed to investigate the level of forward-looking information in Management Commentaries of a sample of companies listed on Italian Stock Exchange for the year 2010. Using content analysis the study confirms that these companies are reluctant to provide forward-looking information in Management Commentaries. Three hypotheses are proposed and six models are tested within a regression analysis in order to explore the effect of three main variables (firm size, profitability and leverage) on forward-looking information. The results show that profitability has significant association with the level of specific types of forward-looking information. Conversely, firm size and leverage are found to be insignificant in explaining the level of forward-looking information.
\end{abstract}

Keywords: forward-looking information, disclosure, firm characteristics, Management Commentary

\section{Introduction}

Forward-looking information has been receiving an increasing amount of attention in recent disclosure studies. The present role of forward-looking disclosure in economic environment is therefore critical since capital markets is too rapid to rely on historical information only. In particular, the dynamic evolution of economic conditions accentuates the potential deficiencies of historical information. Along with economic development, historical disclosure of listed companies cannot satisfy investors' diversified information needs. In some cases historical information is unable to provide sufficient insight to stakeholders, from a forward-looking perspective, regarding critical success factors, opportunities, risks and management plans. Because of the inadequacy of historical information, the request for forecast disclosure provides investors with the needed information to make more advised decisions.

It is believed that disclosure of forward-looking information would improve the ability of investors to assess future cash flows, to forecast future earnings and to make better investment decisions (Hussainey et al., 2003). For instance, Kieso and Weygandt (1995) argued that forecast disclosure is useful to investors in their investment decision-making process. Also a number of studies underlined the effectiveness of forward-looking financial information on which investors base their forecasts (Bozzolan et al., 2009). Especially, the financial community and Accounting Standard Setters such as FASB (2001) and IASB (2010) have increasingly agreed to more voluntary disclosure of forward-looking information as a mean to satisfy investors' information requests. For example, American Institute of Certified Public Accountants (AICPA, 1994), the Canadian Institute of Chartered Accountants (CICA, 2002) and the Institute of Chartered Accountants in England and Wales (ICAEW, 2003), all draw attention to the importance of forward-looking disclosure for informed investors' decision making. Additionally, according to IFRS Practice Statement: Management Commentary - A Framework for presentation (issued by IASB in 2010), the Management Commentary should contain forward-looking information and communicate management's perspective of the company's direction. This information should explain key trends and factors determining future results, position and development of the company and should identify expected opportunities and risks deriving from those conditions.

Before exploring the object of this study, it would be better to address the content of forward-looking 
information. Forward-looking information is the category of information regarding forecasts that allow users to assess a company's future performance. It includes management's plans, assessments of opportunities and risks, and forecasted data about the company's operations. Furthermore, forward-looking information regards financial forecasts such as future earnings, expected returns and anticipated cash flows. This type of information also refers to non-financial information concerning objectives, strategies, risks and uncertainties that could considerably influence current results and expected targets. According to the ICAEW (2003), such forward-looking information entails any information that might have an effect on subsequent financial statements. Studies (Bujaki et al., 1999) that describe the nature of forward-looking information show that this type of information can be quantitative, qualitative, financial or non-financial. In many cases it is possible to recognize forward-looking information by the use of words such as "predict", "expect", "estimate", "anticipate", "forecast" or other comparable terms (Aljifri \& Hussainey, 2007). Anyway Hussainey (2004) argued that the categorization of forward-looking information is not as easy as stated above because some kinds of information categorized as historical could carry messages concerning the future.

In the context of forward-looking information, the nature of the business, management's objectives and strategies, resources, risks and relationships, prospects, forecasted performance of the company and other available information can be provided. The level of this information would be important in estimating the extent to which the company's financial position, liquidity and performance may change in the future (IASB, 2010). Already numerous studies examined empirically the benefits of forward-looking information with respect to corporate future performance (Clarkson et al., 1994; Bryan, 1997).

In our study, we developed hypotheses about the relationship between forward-looking information and firm characteristics that might influence disclosure strategies followed by managers in Italian listed companies. In particular this paper examines the effect of firm characteristics on the level of forward-looking information disclosed in Management Commentary, considering different measures of this kind of information. With this purpose, company characteristics which have a direct impact on the level of forward-looking information are taken into account by a detailed inspection of the pertinent disclosure literature. Our study contributes to the prior studies on disclosure strategies (Quagli, 2008) by showing that the amount of forward-looking information presented in the Management Commentaries is influenced by firm characteristics. It should be noted that a very limited number of studies have examined the impact of firm characteristics on disclosure of forward-looking information and no study yet has analyzed this research topic in Italy. Additionally, the assessment of the level of forward-looking information disclosed by Italian companies will contribute to understanding the dynamics of other markets situated in Europe. Especially, because of its characteristics, Italian market is similar to other developed European markets, so that our study will provide significant evidence to users in other European countries like in Italy.

The paper is organized as follows. Previous literature on forward-looking disclosure is discussed in Section 2. Moreover research hypotheses based on existing theories are developed here. Section 3 presents the Italian business environment and capital market. Section 4 describes the research design, including sample data collection, and explains the research methodology used to achieve the research objectives. Section 5 examines the results of the empirical analysis. Section 6 summarizes research findings and presents the main conclusions of the study, limitations and suggestions for future researches.

\section{Literature Review and Hypotheses Development}

There have been numerous recent studies about the effect of firm characteristics on disclosure (Kent \& Ung, 2003; Alsaeed, 2006) and this topic has received a considerable attention in academic literature. Furthermore, a number of prior studies have analyzed the association between firm characteristics and disclosure of forward-looking information (Meek et al., 1995; Patton, 1997; Celik et al., 2006; Aljifri \& Hussainey, 2007; Abed at al., 2011). However, empirical evidence about the effect of firm-specific attributes on this kind of disclosure is uncertain and sometimes fails to provide conclusive results (Donnelly \& Mulcahy, 2008).

Especially, there is a plenty of studies that tries to investigate what motivates companies to disclose forward-looking information. Some previous studies focused on determinants of the disclosure level of forward-looking information and they have principally centralized on the relations between earnings forecast and firm characteristics. For example a study (Kent \& Ung, 2003) demonstrated that larger companies with less volatile earnings are inclined to disclosure more forward-looking information than smaller companies with comparatively volatile earnings. Other studies analyzed the association between forward-looking information and firm characteristics directly affecting the disclosure behavior of companies and they led us to formulate the hypotheses below. 


\subsection{Profitability}

The association between profitability and voluntary disclosure has been investigated in prior literature (Oyelere et al., 2003; Marston, 2003; Marston \& Polei, 2004; Wang et al., 2008) and much evidences in empirical research confirmed the role of profitability as a determinant of level of corporate disclosure (Cerf, 1961; Wallace et al., 1994; Skinner, 1994; Frankel et al., 1995; Lang \& Lundholm, 1996; Tasker, 1998). However other studies (Ahmed \& Courtis, 1999) argued that empirical evidence on the relationship between profitability and disclosure is unclear because provides mixed results. Indeed some of studies agree on the existence of a positive relationship between profitability and voluntary disclosure (Singhvi, 1968; Singhvi \& Desai, 1971; Wallace et al., 1994). For example, Singhvi and Desai (1971) observed that higher profitability might encourage management to disclosure more financial information about the ability to maximize the shareholders' value. Differently, a significant negative correlation between profitability and the level of disclosure has also been demonstrated (Belkaoui \& Kahl, 1978). For instance, according to Wallace and Naser (1995) profitable companies may not provide further information because their investors are particularly gratify. Other studies instead (McNally et al., 1982; Lau, 1992; Raffournier, 1995; Ettredge et al., 2002; Aljifri, 2006) indicated an insignificant relationship between profitability and disclosure level. Similarly, according to Alsaeed (2006) profitability was found to be irrelevant in signaling the variation of voluntary disclosure.

With regard to forecast information, Aljifri and Hussainey (2007) stated a significant correlation between profitability and the level of forward-looking information. Furthermore, a positive relationship between forward-looking information and performance was observed in previous literature on forecast disclosures (Firth, 1979; Cooke, 1989; Hossain et al., 1995; Prencipe, 2004). The majority of literature claimed that firms with higher profit margin are more likely to disclose additional forward-looking information than those with lower return on equity (Cahan \& Hossain, 1996). However, Walker and Tsalta (2001), Kent and Ung (2003) and Hossain et al. (2005) found no such correlation between performance and the extent of forward-looking information and especially other prior studies documented a negative association between forecast disclosures and profitability (Celik et al., 2006; Aljifri \& Hussainey 2007, Abed et al., 2011).

In accordance with prior literature (Vanstraelen et al., 2003; Hossain et al., 2005; Beretta \& Bozzolan, 2008; Bravo et al., 2009), this study considers return on equity as profitability-related measure and derives it by dividing net income available for stakeholders by book value of owners equity. Based on previous literature a firm's profitability has been stated to be positively associated with forward-looking information. Hence, with respect to the majority of disclosure literature mentioned above, the following hypothesis is stated:

\section{$H_{1}$ : There is positive association between profitability and the level of forward-looking information.}

\subsection{Firm Size}

Much evidence of prior studies on the determinants of corporate disclosure has documented the existence of an interactive effect between firm size and its level of forward-looking disclosure (Cerf, 1961; Cooke, 1991). Notably, a stream of empirical research has found that larger companies are more inclined to disclose greater amount of disclosure (Wallace et al., 1994; Beattie et al., 2004; Hassan et al., 2006; Alsaeed, 2006) and to follow better disclosure practices (Ahmed \& Courtis, 1999). In particular, empirical findings from previous studies demonstrated that total level of forward-looking information is positively related with company size (Walker \& Tsalta, 2001; Kent \& Ung, 2003; Vanstraelen et al., 2003; Leventis \& Weetman, 2004; Gao et al., 2005; Hossain et al., 2005; Celik et al., 2006; Celik et al., 2006; Lim et al., 2007; Hossain \& Hammami, 2009; Abed et al., 2011). There are several reasons for such a positive relationship. For instance Hassan et al. (2006) argued that large companies might have a lot of resources to sustain additional information costs if they provide more relevant disclosure to different users.

Just two studies, instead, have attested the absence of significant relationship between firm size and forward-looking information (Aljifri, 2006; Aljifri \& Hussainey, 2007) because findings have shown that companies of varying sizes tend to have no differences in their forward-looking disclosure.

Literature review suggests a broad variety of criteria for measuring the size of a company, such as capital employed and sales turnover (Firth, 1979), total assets and turnover (Cooke, 1991) and the market capitalization (Debrency et al., 2002). In our study, we measure the firm size (SIZE) by book value of total assets. Based on some of prior studies, we hypothesize that:

$\mathrm{H}_{2}$ : There is positive association between firm size and the level of forward-looking information.

\subsection{Leverage}

Leverage is another variable generally employed in previous literature to investigate the determinants of 
corporate disclosure. Empirical results from prior studies provided mixed evidence on the association between leverage and disclosure behavior. For example, some studies demonstrated a significant linkage between disclosure level and leverage (Malone et al., 1993; Hossain et al., 1994; Wallace et al., 1994), while others failed to find any support for the proposed relationship between the two variables (Chow \& Wong-Boren, 1987; Ahmed \& Nicholls, 1994; Wallace \& Naser, 1995; Hossain et al., 1995; Raffournier, 1995; Celik et al., 2006).

Yet, much results of prior studies (Belkaoui \& Kahl, 1978; Malone et al., 1993; Wallance et al., 1994; Zarzeski, 1996; Ahmed \& Courtis, 1999) confirmed that highly leveraged firms tend to disclose more information than less leveraged firms in order to satisfy creditors' needs for disclosure. For example O'Sullivan et al. (2008) recognized leverage as a variable positively influencing the amount of voluntary disclosure. Also some of the researchers in "agency theory" claim that the higher the debt to equity levels, the greater the amount of information a company may disclosure (Watts, 1977). For instance, Jensen and Meckling (1976) and Smith and Warner (1979) have observed that agency costs are higher for companies with high debt ratio, suggesting a positive relationship between the amount of financial disclosure and financial leverage. It is argued that such companies are more likely to share more important information with their lenders to reduce financial costs. Moreover, some of the literature concerning forward-looking information confirmed that there is a positive relationship between leverage and corporate forward-looking information (Ahmed \& Courtis, 1999; Bravo et al., 2006). For example debt ratio is found to have a significant association with the level of forward-looking information (Aljifri \& Hussainey, 2007). Conversely, Celik et al. (2006) failed to find any validation for the correlation between leverage and forward-looking information.

We employ as a measure for leverage the debt to equity ratio that is defined as total debt divided by book value of equity. The results of some of the previous studies lead us to the following hypothesis:

\section{H3: There is positive association between leverage and the level of forward-looking information.}

\section{The Italian Business Environment and Capital Market}

This study is conducted in Italy, a developed country situated in Europe. With a population of almost 60 million, Italy is one of the largest and most affluent markets in the European Union. Given its size, there are significant opportunities for economies of scale. Its business environment is also extremely sophisticated, producing goods high on the value chain. Italy has a diversified industrial economy, which is divided into a developed industrial north, dominated by private companies, and a less-developed, welfare-dependent, agricultural south, with high unemployment. The Italian economy is driven in large part by the manufacture of high-quality consumer goods produced by small and medium-sized enterprises. Italy also has a sizable underground economy, which by some estimates accounts for as much as $15 \%$ of GDP. These activities are most common within the agriculture, construction, and service sectors.

Italy is the third-largest economy in the euro-zone, but its exceptionally high public debt and structural impediments to growth have rendered it vulnerable to scrutiny by financial markets. But while it vaunts one of the most affluent and largest markets in Europe, Italy has made a number of improvements in policy affecting business and it faces stiff competition from many of its European neighbors for attracting corporate headquarters operations. Public debt has increased constantly since 2007, so that during the second half of 2011 the government passed a series of three austerity packages to decrease its public debt and to balance its budget. These measures included a hike in the value-added tax, pension reforms, and cuts to public administration. The government also faces pressure from investors and European partners to sustain its recent efforts to address Italy's long-standing structural impediments to growth, such as an inflexible labor market and widespread tax evasion. According to the World Economic Forum (WEF), Italy's institutional weaknesses include high levels of corruption, organized crime and a perceived lack of independence in the judicial system, all of which increase business costs and undermine investor confidence. There are also structural weaknesses in the labor market, which impede both job creation and efficiency. Italy's low levels of mobility make it one of the most rigid labor markets in the European Union. The taxation system also impacts Italy's attractiveness.

Among European countries Italy has the second-largest securitization market, lagging only behind the UK with respect to asset value, securities issued and the volume of such transactions. Borsa Italiana, based in Milan, is the main Stock Exchange in Italy and it is part of the London Stock Exchange Group plc since 2007. It is the primary market for derivatives traded in Italy, as well as for Italian government bonds and eurobonds. It also trades in other fixed income investments. Borsa Italiana organizes and manages the Italian stock market with the participation of nearly 130 domestic and international brokers that operate in Italy or from abroad through remote membership, using a completely electronic trading system for the real-time execution of trades. The Borsa Italiana's main Indices are: the FTSE MIB, a capitalization-weighted Index of 40 of the biggest companies 
chosen to represent 10 economic sectors, and the MIBTel, which covers all Italian shares (and certain foreign ones) listed on the MTA and on the MTAX market.

\section{Methodology}

The level of forward-looking information is measured by examining the Management Commentaries of Italian listed companies included in the FTSE-Mib Index. We selected this Index because it is the main benchmark and the major stock market Index which tracks the performance of large companies based in Italy and it represents approximately $80 \%$ of the domestic market capitalization. FTSE-Mib Index consists of leading Italian companies operating in different sectors and having highest market capitalization and liquidity, so that this Index represents a wide cross-section of industries and it presents an appropriate portrayal of the overall Italian stock market. This provided us with a population of the top 40 quoted companies at the end of 2010. Clearly this not a random sample and it is representative of a large number of Italian companies whose financial statements are drawn up under IAS/IFRS. Regarding the period of the analysis, we focused on Management Commentaries for the year 2010. Accounting year 2010 is of interest principally because entities may apply IASB's guidelines concerning forward-looking information in Management Commentary (IASB, 2010) presented prospectively from 8 December 2010. As a result, year 2010 is the first reporting period ending since this application date. To conduct the study analysis was restricted to one year also because disclosure strategies generally tend to be continual over time (Botosan, 1997). The number of observations provides a good reliability to draw relevant conclusions according to some prior empirical studies on disclosure which selected a similar sample size (Cooke, 1992; Jaggi \& Low, 2000; Alsaeed, 2006). Moreover the sample mean of at least 30 observations is nearly normal (Gujarati, 2006).

Each Management Commentary of financial year 2010 was downloaded directly from selected companies' websites and was individually scrutinized in order to determine forward-looking information strategies lead by companies. Quantity of forward-looking information disclosed in Management Commentaries was measured by the method of content analysis that has been widely applied to quantify the extent of disclosure in previous studies (Harte \& Owen, 1991; Cunnigham \& Gadenne, 2003; Beatti et al., 2004). Content analysis needs the selection of recording units, such as a word, or a group of words, or a sentence, or a paragraph or an entire document. This research takes "word" as a recording unit because it is deemed a more reliable unit of analysis than the number of sentences or the number of paragraphs (Hackston \& Milne, 1996). A paragraph or a sentence is also not a suitable recording unit as a sentence may contain a mix of disclosure items including different information that provides insight into the company's past results and prospects. Furthermore in the context of content analysis we found that in most examined Management Commentaries a single sentence contains frequently information concerning several types of information. Thus we used the word as recording unit since it reduces the subjectivity of coders and it represents a reliable measure of the quantity of disclosure.

A scoring system based on content analysis (Zoccarato, 2012) is constructed to measure the level of forward-looking information disclosed in every Management Commentary and in particular an unweighted approach is implemented (Cooke, 1998). This approach gives the same importance to all items of forward-looking information to avoid subjective judgment of assigning weights to information items, since this research is concerned with the level of disclosure rather than the importance of disclosed items. As a result each word with forward-looking information is computed one point under the scoring system. Pictures, captions to pictures of activities, graphs and diagrams are kept out from the analysis as enclosure of them would imply a high level of subjectivity (Ahmed \& Sulaiman, 2004), so that the content analysis encompasses only narrative text (qualitative and quantitative).

A Disclosure Index is formulated to inspect the content of forward-looking disclosure (Marston, 1991). Without a definite academic literature concerning the content of forward-looking disclosure, we built a checklist of specific disclosure items using the guidelines issued by IASB for Management Commentary (IASB, 2010). In this phase we define the coding procedure to catch the disclosure of forward-looking information and we use a checklist that classify items of information disclosed.

In order to verify the value of dependent variables, we organized forward-looking information in four categories:

- The Nature of the Business (NOB)

- Objectives and Strategies (OBS)

- Resources, Risks and Relationships (RRR)

- Results and Prospects (REP)

The categories used for classification and counting words with forward-looking information are taken from the 
list developed by IASB for Management Commentary (IASB, 2010). In particular these four categories are divided in 15 items chosen by following the suggestions from IASB's Practice Statement for Management Commentary (Menicucci, 2012). IASB outlines several detailed items which were deemed useful to users. Hence it allows us to develop a comprehensive Disclosure Index that can be used to investigate the extent of forward-looking disclosure. The list of items is presented in Table 1.

Table 1. Disclosure index composition

\begin{tabular}{|c|c|}
\hline Categories & Types of information \\
\hline $\begin{array}{l}\text { I. The Nature of the Business } \\
\text { (NOB) }\end{array}$ & $\begin{array}{l}\text { 1. The industries in which the entity operates } \\
\text { 2. The entity's main markets and competitive position within those markets } \\
\text { 3. Significant features of the legal, regulatory and macroeconomic environments } \\
\text { 4. The entity's main business processes, distribution methods, products and services } \\
\text { 5. The entity's structure }\end{array}$ \\
\hline $\begin{array}{l}\text { II. Objectives and Strategies } \\
\text { (OBS) }\end{array}$ & $\begin{array}{l}\text { 6. Objectives } \\
\text { 7. Strategies } \\
\text { 8. Relationship between objectives, strategy and management actions }\end{array}$ \\
\hline $\begin{array}{l}\text { III. Resources, Risks and } \\
\text { Relationships (RRR) }\end{array}$ & $\begin{array}{l}\text { 9. Critical financial and non-financial resources available to the entity and how those resources are employed } \\
\text { in achieving management's stated objectives } \\
\text { 10. Analysis of the adequacy of the entity's capital structure, financial arrangements, liquidity and cash } \\
\text { flows, human and intellectual capital resources } \\
\text { 11. Entity's principal risk (strategic, commercial, operational and financial) exposures } \\
\text { 12. Plans and strategies for bearing or mitigating risks and effectiveness of risk management strategies } \\
\text { 13. Significant relationships that the entity has with stakeholders, how those relationships are likely to } \\
\text { influence the performance and value of the entity, and how those relationships are managed }\end{array}$ \\
\hline $\begin{array}{l}\text { VI. Results and Prospects } \\
\text { (REP) }\end{array}$ & $\begin{array}{l}\text { 14. Financial and non-financial future performance } \\
\text { 15. Management's assessment of the entity's prospects }\end{array}$ \\
\hline
\end{tabular}

All Management Commentaries are analyzed to verify the number of words with forward-looking information disclosed by each company. The analysis of information is broken down into partial information categories and content analysis is used to identify and classify words with forward-looking information in the categories. That is, each Management Commentary is scrutinized searching for every set of words containing forward-looking information ranking in the categories and then words giving forward-looking information are counted. For valid regressions to be drawn, it is important that the classification procedure be reliable and valid (Krippendorff, 1980; Weber, 1985). Thus the Disclosure Index composition is reviewed by two researchers and then the coding rules for classification of disclosure are re-confirmed by two researchers' supervisors in order to ensure consistency and to assess reliability (Note 1).

Forward-looking disclosure strategies are investigated by the consideration of different information attributes: information quantity, information coverage and distribution of information among the four diverse mentioned categories. As a result, various measures of forward-looking information are included as dependent variables in the empirical analysis that inspects the relationship between firm characteristics and forward-looking disclosure strategies. The measure of quantity (QNT) is included in the analysis, taking into account the number of words containing forward-looking information. Other measures of information are also considered. The measure of coverage (COV) considers the number of words concerning forward-looking information divided by the total number of words disclosed. Moreover, we employ some measures which apply the proportion of forward-looking information disclosed on each of the categories described in Table 1. Therefore, forward-looking disclosure strategies are examined by looking at different measures of forward-looking information: quantity (QNT); coverage (COV); information about the Nature of the Business (NOB), information about Objectives and Strategies (OBS), information about Resources, Risks and Relationships (RRR), information about Results and Prospects (REP). Each of these measures is alternatively included in the statistical analysis.

In order to investigate, firstly, the level of forward-looking information and to identify, secondly, its determinants, we adopted both a descriptive analysis and a multivariate analysis. As in many prior disclosure studies, multivariate analysis is carried out using a OLS-regression model in order to explore the joint effect of firm characteristics on the level of forward-looking information in Management Commentaries of selected companies. Six Models are tested in the analysis, and each one includes a different measure of forward-looking 
information (dependent variable). Specifically, the regression analysis includes alternatively different measures of forward-looking information as dependent variables (QNT, COV, NOB, OBS, RRR and REP) and three independent variables. On the basis of previous literature, we employ as a measure for firm characteristics the variables described in the hypotheses development. Therefore the independent variables considered in this study are the following: ROE (Profitability, measured by return on equity); SIZE (Firm size, measured by book value of total assets); LEV (Leverage, measured by total debt to equity).

The explanations of dependent and independent variables employed in the analysis are presented in Table 2.

Table 2. Explanation of variables

\begin{tabular}{|c|c|c|}
\hline Varial & Description & Measure \\
\hline \multicolumn{3}{|c|}{ Dependent variables } \\
\hline QNT & Quantity of forward-looking information & Number of words containing forward-looking information \\
\hline $\mathrm{COV}$ & Coverage of forward-looking information & Proportion of forward-looking information disclosed \\
\hline NOB & $\begin{array}{l}\text { Forward-looking information about the Nature of the } \\
\text { Business }\end{array}$ & $\begin{array}{l}\text { Percentage of forward-looking information about the Nature of the } \\
\text { Business }\end{array}$ \\
\hline OBS & $\begin{array}{l}\text { Forward-looking information about Objectives and } \\
\text { Strategies }\end{array}$ & $\begin{array}{l}\text { Percentage of forward-looking information about Objectives and } \\
\text { Strategies }\end{array}$ \\
\hline RRR & $\begin{array}{l}\text { Forward-looking information about Resources, Risks and } \\
\text { Relationships }\end{array}$ & $\begin{array}{l}\text { Percentage of forward-looking information about Resources, Risks } \\
\text { and Relationships }\end{array}$ \\
\hline REP & Forward-looking information about Results and Prospects & $\begin{array}{l}\text { Percentage of forward-looking information about Results and } \\
\text { Prospects }\end{array}$ \\
\hline \multicolumn{3}{|c|}{ Independent variables } \\
\hline ROE & Return on equity (ROE) & Net income/Equity \\
\hline SIZE & Company size & Total assets (million of Euro) \\
\hline LEV & Leverage & Total debt/Equity \\
\hline
\end{tabular}

The OLS-regression analysis is used to test the hypotheses of this study and the regression model is given by:

$$
F L I=\beta_{0}+\beta_{1} R O E+\beta_{2} S I Z E+\beta_{3} L E V+e
$$

where,

FLI refers to forward-looking information disclosed by each company. Different measures are alternatively included in the analysis (quantity - QNT -, coverage - COV -, information about the Nature of the Business NOB -, information about Objectives and Strategies - OBS -, information about Resources, Risks and Relationships - RRR -, information about Results and Prospects - REP -); $\beta$ is the regression coefficient; $i=$ $0,1,2,3$; ROE refers to profitability; SIZE refers to the size of company; LEV refers to leverage; $e$ is the error term.

\section{Results and Discussion}

This section examines the empirical methods used to verify the research hypotheses of the study and illustrates the results. It includes two statistical methods: a descriptive analysis and a regression analysis.

\subsection{Descriptive Analysis}

Table 3 presents the results of descriptive analysis regarding the level of forward-looking information disclosed by the firms and the measures of companies' characteristics which are included in the analysis.

Table 3. Descriptive analysis

\begin{tabular}{lllll}
\hline Variables & Minimum & Maximum & Mean & Std. Deviation \\
\hline Dependent variables & & & & \\
\hline QNT & 91.000 & 4833.000 & 1006.750 & 1023.750 \\
COV & 0.003 & 0.163 & 0.030 & 0.028 \\
NOB & 0.000 & 0.847 & 0.325 & 0.238 \\
OBS & 0.000 & 0.712 & 0.189 & 0.183 \\
RRR & 0.000 & 0.794 & 0.230 & 0.250 \\
REP & 0.025 & 1.000 & 0.257 & 0.191 \\
\hline Independent variables & & & \\
\hline ROE & -36.420 & 28.620 & 10.202 & 10.788 \\
SIZE & 0.448 & 244278.936 & 8502.435 & 52769.522 \\
LEV & 0.090 & 5.650 & 1.065 & 1.256 \\
\hline
\end{tabular}


The Table reports the minimum, maximum, mean and standard deviation for the variables in the sample data set. The results presented in Table 3 document that companies disclose a small number of words with forward-looking information. A wide range of variations of forward-looking information is also found. The quantity of forward-looking information has remarkable dispersion in the scores, as shown by the minimum, maximum and standard deviation values. The extent of forward-looking information ranges from 91.000 to 4833.000. On average Italian listed companies provide 1006.750 words related to forward-looking information, which indicate low level of this disclosure across the companies. Minimum and maximum values of coverage show a low proportion of forward-looking information disclosed in Management Commentaries. Results could be appreciated on the basis that in Italy no effective regulations enforce managers to divulge forward-looking-information. Within the sample, a wide range of variation is evident also with regard to the independent variables as represented by their minimum and maximum values. The firm size ranges from 0.448 to 244278.936 with a mean of 8502.435 and a standard deviation of 52769.522 . The profitability ranges from -36.420 to 28.620 with a mean of 10.202 and a standard deviation of 10.788 , while the leverage ratio ranges from 0.090 to 5.650 with a mean of 1.065 and a standard deviation of 1.256 .

Interestingly, forward-looking disclosure referable to the four information categories indicates very significant differences across the companies that compose the sample. Percentage of forward-looking information about each of all the categories covered in our study has considerable dispersion in the scores, as represented by the minimum, maximum and standard deviation. For instance forward-looking information about the Nature of the Business ranges from 0 to 0.847 with a mean of 0.325 . On average, companies release more forward-looking information about the Nature of the Business topics (approximately $32.5 \%$ over the total forward-looking information disclosed by companies), even though some firms do not disclosed this kind of information. The low disclosure level of forward-looking information for each of the four information categories most likely relates to the fact that these types of information are voluntary because in Italy no existing disciplines require companies to display forward-looking information concerning specific items. Moreover IASB proposed a framework to assist in the preparation of Management Commentary that accompanies financial statements drawn up in accordance with IAS/IFRS. Anyway these proposals are only non-mandatory guidelines issued by IASB for the preparation of a decision-useful Management Commentary and a company is not required to comply with the IASB's framework for Management Commentary in order to assert compliance with IAS/IFRS. In other words, the extent of forward-looking disclosure in Management Commentary of Italian listed companies applying IAS/IFRS and being subject to national requirements is left to the discretion of management and regarding this issue our findings confirm that all the companies included in the sample are loath to provide forward-looking information in Management Commentary.

\subsection{Regression Analysis}

Before carrying out the regression analysis, the existence of an econometric problem of data set applied in the model is tested by using the correlation matrix. We have checked the independence of variables to be secured the absence of multicollinearity problems that may prejudice our results.

Table 4 presents correlation coefficients for the variables included in the analysis.

Table 4. Correlation matrix

\begin{tabular}{|c|c|c|c|c|c|c|c|c|c|}
\hline Variables & QNT & $\mathrm{COV}$ & NOB & OBS & RRR & REP & ROE & SIZE & LEV \\
\hline QNT & 1.0000 & & & & & & & & \\
\hline $\mathrm{COV}$ & 0.6361 & 1.0000 & & & & & & & \\
\hline NOB & -0.3251 & -0.2843 & 1.0000 & & & & & & \\
\hline OBS & 0.0020 & -0.0719 & -0.2410 & 1.0000 & & & & & \\
\hline RRR & 0.4896 & 0.4892 & -0.5755 & -0.2944 & 1.0000 & & & & \\
\hline REP & -0.2785 & -0.2413 & -0.2705 & -0.1878 & -0.3698 & 1.0000 & & & \\
\hline ROE & -0.1977 & -0.0239 & -0.2377 & $-0.2908^{*}$ & 0.1311 & $0.3691 * *$ & 1.0000 & & \\
\hline SIZE & 0.0682 & -0.0432 & 0.0461 & -0.0074 & 0.0073 & -0.0689 & -0.0439 & 1.0000 & \\
\hline LEV & 0.0100 & 0.0429 & -0.0048 & -0.0252 & 0.1127 & -0.1282 & -0.1064 & $0.3449 *$ & 1.0000 \\
\hline
\end{tabular}

Notes: **Significant at the 0.05 level (two-tailed); *Significant at the 0.10 level (two-tailed).

The results confirm that no collinearity problem subsists between the independent variables. The correlation between each of the variables is not elevated and the highest correlation found between leverage and firm size is very acceptable. As a result the coefficients indicate that the model is valid and reliable, so that a univariate 
analysis can be performed by examining individual correlations between independent and dependent variables. Indeed results show that there is a significant correlation between profitability and both forward-looking information about Objectives and Strategies (at 0.05 level) and forward-looking information about Results and Prospects (at 0.10 level).

Table 5 displays the results of OLS-regression analysis.

Table 5. Regression analysis

\begin{tabular}{|c|c|c|c|c|}
\hline & Coefficient & Std. Error & t-ratio & p-value \\
\hline \multicolumn{5}{|c|}{ Model 1 - Dependent variable: QNT } \\
\hline const & 1234.25 & 282.85 & 1.3636 & 0.00010 \\
\hline ROE & -19.0029 & 15.5426 & -1.2226 & 0.22941 \\
\hline SIZE & 0.00238434 & 0.00496738 & 0.4800 & 0.63413 \\
\hline LEV & -50.6125 & 159.032 & -0.3183 & 0.75213 \\
\hline \multicolumn{5}{|c|}{ Model 2 - Dependent variable: COV } \\
\hline const & 0.028939 & 0.00793447 & 3.6473 & 0.00083 \\
\hline ROE & $-4.75126 \mathrm{e}-05$ & 0.000436 & -0.1090 & 0.91383 \\
\hline SIZE & $-6.64397 \mathrm{e}-08$ & $1.39345 \mathrm{e}-07$ & -0.4768 & 0.63639 \\
\hline LEV & 0.00207317 & 0.00446116 & 0.4647 & 0.64493 \\
\hline \multicolumn{5}{|c|}{ Model 3 - Dependent variable: NOB } \\
\hline const & 0.398411 & 0.0653797 & 6.0938 & $<0.00001$ \\
\hline ROE & -0.00523031 & 0.00356079 & -1.4689 & 0.15080 \\
\hline SIZE & $4.26628 \mathrm{e}-07$ & $1.13246 \mathrm{e}-06$ & 0.3767 & 0.70865 \\
\hline LEV & -0.0132128 & 0.0362612 & -0.3644 & 0.71777 \\
\hline \multicolumn{5}{|c|}{ Model 4 - Dependent variable: OBS } \\
\hline const & 0.249659 & 0.0494301 & 5.0507 & 0.00001 \\
\hline ROE & -0.00503913 & 0.00271619 & -1.8552 & $0.07177 *$ \\
\hline SIZE & $6.83101 \mathrm{e}-08$ & $8.68087 \mathrm{e}-07$ & 0.0787 & 0.93771 \\
\hline LEV & -0.00945779 & 0.277921 & -0.3403 & 0.73560 \\
\hline \multicolumn{5}{|c|}{ Model 5 - Dependent variable: RRR } \\
\hline const & 0.163089 & 0.0694181 & 2.3494 & 0.02441 \\
\hline ROE & 0.0033847 & 0.00381453 & 0.8873 & 0.38080 \\
\hline SIZE & $-4.9999 \mathrm{e}-07$ & $1.2912 \mathrm{e}-06$ & -0.4101 & 0.68414 \\
\hline LEV & 0.0342337 & 0.0390304 & 0.8771 & 0.38625 \\
\hline \multicolumn{5}{|c|}{ Model 6 - Dependent variable: REP } \\
\hline const & 0.20622 & 0.498635 & 4.1357 & 0.00020 \\
\hline ROE & 0.00635307 & 0.00274001 & 2.3186 & $0.02621 * *$ \\
\hline SIZE & $-2.83342 \mathrm{e}-08$ & $8.75699 \mathrm{e}-07$ & -0.0324 & 0.97437 \\
\hline LEV & -0.0131513 & 0.0280358 & -0.4691 & 0.64183 \\
\hline
\end{tabular}

Notes: **Significant at the 0.05 level (two-tailed); *Significant at the 0.10 level (two-tailed).

The regression analysis reveals that the level of forward-looking information is affected only by profitability. ROE is found to have a statistically significant relationship with forward-looking information, whereas the other two independent variables (size and leverage) are found to have an insignificant effect on the level of disclosure related to the future. Table 5 contains regression results regarding each Model. Model 1 and Model 2 display the impact of firm characteristics respectively on quantity and coverage of forward-looking information. Models from 3 to 6 show the relationship between firm characteristics and different categories of forward-looking information.

For hypotheses testing, results document that ROE influences specific kind of forward-looking information published in Management Commentaries, but has no association with quantity and coverage of forward-looking information. Especially, regression results show that ROE affects negatively forward-looking information about Objectives and Strategies and positively forward-looking information about Results and Prospects.

Thus, Hypothesis 2 which purports a positive association between profitability and information related to the future is not supported by empirical evidence for quantity (Model 1) and coverage (Model 2) of forward-looking information. Neither results concerning forward-looking information about the Nature of the Business (Model 3) 
nor those about Resources, Risks and Relationships (Model 5) indicate any significant association with ROE.

Regarding Model 4, results reveal that companies with more profitability tend to provide less redundant forward-looking information about objectives and strategies. ROE influences negatively on this category of forward-looking information (the value of the coefficient is - 0.00503913 , being significant at the level of 0.10 ). The value of the regression coefficient shows that companies with high profitability tend to disclose less forward-looking information about objectives and strategies. One probable reason for the results regarding this type of information is that Italian managers are reluctant to disclose information including future strategies and objectives, even if this information is extremely useful to improve analysts' forecasts and transparency in capital markets. These findings disprove the Hypothesis 2 but are consistent with a number of studies (Aljifri \& Hussainey 2007; Abed et al., 2011) that find a negative relationship between profitability and forward-looking information. In short, companies with low profitability tend to disclose more forward-looking information about Objectives and Strategies.

Conversely, Hypothesis 2 is supported by Model 6 tested in our study. Results show positive and statistically significant relationship between profitability and the level of forward-looking information about Results and Prospects. The coefficient, significant at the level of 0.05 , presents a value of 0.00635307 . Hence, the value of the coefficient indicates that companies with high profitability are more likely to disclosure forward-looking information concerning results and prospects. This is likely arising because profitable companies would tend to convey a positive message about future results, plans and projects to help stakeholders to forecast future financial performance and to assess opportunities and risks. Another possible explanation for the results is that such companies would share more future information with their stakeholders. Especially profitable companies are generally inclined to disclosure more forward-looking information about Results and Prospects to assure stakeholders and to decrease risk premium in rate of return on equity.

Regarding other independent variables our Hypotheses are not supported by findings of our study. Regression analysis shows that firm size and leverage have an insignificant influence on the level of forward-looking information. Regression results disprove a correlation between these independent variables and all the measure of forward-looking information considered in the analysis as dependent variables. This is in contrast to our Hypothesis 1 and Hypothesis 3 which respectively state that the extent of forward-looking information disclosed by Italian companies is positively related to firm size and to leverage. Regression results in fact disprove an association between forward-looking disclosure and these two variables. Hence, Hypotheses 1 and 3 are rejected. Although our findings are consistent with a number of previous studies which suggested an insignificant relationship between these variables and disclosure of forward-looking information. For example, Aljifri (2006) disproves an association between the level of forward-looking disclosure and firm size. As well, Celik et al. (2006) show an insignificant relationship between leverage and the level of forward-looking information.

\section{Conclusions}

The aim of this paper is to investigate the effect of three firm characteristics on forward-looking disclosure in the Management Commentaries of Italian listed companies. The regression results for the sample of 40 companies show that profitability is the only determinant of forward-looking disclosure. On the contrary, our findings demonstrate that the other two independent variables (firm size and leverage) have an insignificant correlation with the level of forward-looking information. Furthermore the contribution of profitability is found to be significantly related to specific types of forward-looking information published in Management Commentaries. In particular profitability is found to influence negatively on forward-looking information about Objectives and Strategies and positively on forward-looking information about Results and Prospects.

This research study adds to the prior literature by exploring the effect of firm characteristics on the disclosure of forward-looking information. It is believed that this study will improve the insight of the variables that could impact on forward-looking information in Italian listed companies. There are a very restricted number of studies that have explained the variation of forward-looking information in the light of firm characteristics and acquired results are ambiguous. Thus this study is deemed to contribute to the current literature concerning forward-looking information. Even though there are a wide number of disclosure studies, only a few are focusing on forward-looking disclosure in Management Commentary. Besides, a limited number of studies have investigated forward-looking disclosure in developed countries and even fewer in Europe.

The findings of this study have important implications. First, the results provide comprehensive insight into the current forward-looking disclosure practices in Italy and can be a useful evidence for preparers of financial reporting, since in Italy no research paper yet has examined the determinants of forward-looking information in Management Commentary. Secondly, the study will assist Italian and European investors in their decision 
making process and will especially be significant for the institutional investors looking for profitable and secure investment opportunities. Furthermore acquired results can be seen as an effort to understand the core characteristics of companies not only in Italy but also in other European countries where companies applying IAS/IFRS operate in markets characterized by similar macro economic conditions and instabilities.

Based on this study, several others can be conducted by inspecting other variables that may affect the extent of forward-looking information and also by examining other types of reports. Moreover future research may be done by increasing the number of companies analyzed or by including further variables to improve the reliability of findings presented in this study. Future research could also measure the level of forward-looking information for more than one year to inspect whether disclosure level has increased over time. By doing this, the quality of the analysis may be increased and thus users may be better pleased.

As with any research, this study has some limitations. First the research is restricted to Italian companies and by sample size. Second, the items composing the Disclosure Index were subjectively combined from the existing IASB's model of good practice (Kabalski, 2012) regarding Management Commentary (IASB, 2010). Third, the measure of forward-looking information is based on an unweighted approach. As a result the application of an equal weight for each word with forward-looking information in the content analysis does not reflect the importance of disclosure as perceived by users. For instance, quantitative forward-looking disclosure items are more relevant than other types of information and some disclosure topics may have a greater value relevance over other items to one particular industry than to others. Regarding this limitation, future research may be carried out by assigning more weight for more significant forward-looking information.

\section{References}

Abed, S., Al-Okdeh, S., \& Nimer, K. (2011). The Inclusion of Forecasts in the Narrative Sections of Annual Reports and their Association with Firm Characteristics: The Case of Jordan. International Business Research, 4(4), 264-271. http//dx.doi.org/10.5539/ibr.v4n4p264

Ahmed, K., \& Courtis, J. K. (1999). Association between corporate characteristics and disclosure levels in annual reports: a meta-analysis. The British Accounting Review, 31(1), 35-61. http//dx.doi.org/10.1006/bare.1998.0082

Ahmed, K., \& Nicholls, D. (1994). The impact of non financial company characteristics on mandatory compliance in developing countries: the case of Bangladesh. International Journal of Accounting, 29(1), 62-77.

AICPA. (1992). Special Committee on financial reporting. Improving business reporting: a customer focus. New York.

Aljifri, K. (2006). Annual report disclosure in a developing country: the case of the UAE. Working Paper, United Arab University, Al Ain.

Aljifri, K., \& Hussainey, K. (2007). The determinants of forward-looking information in annual reports of UAE companies. Managerial Auditing Journal, 22(9), 881-894. http//dx.doi.org/10.1108/02686900710829390

Alsaeed, K. (2006). The association between firm-specific characteristics and disclosure: the case of Saudi Arabia. Managerial Auditing Journal, 21(5), 476-96. http//dx.doi.org/10.1108/02686900610667256

Beattie, V., McInnes, B., \& Fearnley, S. (2004). A methodology for analyzing and evaluating narratives in annual reports: a comprehensive descriptive profile and metrics for disclosure quality attributes. Accounting Forum, 28(3), 205-236. http//dx.doi.org/10.1016/j.accfor.2004.07.001

Belkaoui, A., \& Kahl, A. (1978). Corporate financial disclosure in Canada. Research Monograph, No. 1, Canadian Certified General Accountants Association, Vancouver.

Beretta, S., \& Bozzolan, S. (2008). Quality versus Quantity: the Case of Forward-Looking Disclosure. Journal of Accounting, Auditing \& Finance, 23(39), 333-375. http//dx.doi.org/10.1177/0148558X0802300304

Botosan, C. A. (1997). Disclosure level and the cost of equity capital. The Accounting Review, 72(3), 323-349. Retrieved from http://www.jstor.org/stable/248475

Bozzolan, S., Trombetta, M., \& Beretta, S. (2009). Forward looking disclosure and analysts' forecasts: a study of cross-listed European Firms. European Accounting Review, 18(3), 435-473. http//dx.doi.org/10.1080/09638180802627779

Bravo, F. U., Abad, M. C. N., \& Trombetta, M. (2009). Disclosure Indices Design: Does it Make A Difference? Spanish Accounting Review, 12(2), 253-277. 
Bryan, S. H. (1997). Incremental information content of required disclosures contained in management discussion and analysis. The Accounting Review, 72(2), 285-301. Retrieved form http://www.jstor.org/stable/248557

Bujaki, A., Zeghal, D., \& Bozec, R. (1999). The disclosure of future oriented information in annual reports of Canadian corporations. Working Paper, No. 44, University of Ottawa, Ottawa.

Cahan, S. F., \& Hossain, M. (1996). The investment Opportunity Set and Disclosure Policy Choice: some Malaysian Evidence. Asia Pacific Journal of Management, 13(1), 68-85. http//dx.doi.org/10.1007/BF01739682

Celik, O., Ecer, A., \& Karabacak, H. (2006). Disclosure of forward looking information: evidence from listed companies on Istanbul Stock Exchange (ISE). Investment Management \& Financial Innovation, 3(2), 197-216.

Cerf, R. A. (1961). Corporate Reporting and investment decisions. Berkeley: University of California Press.

Chow, C., \& Wong-Borne, A. (1987). Voluntary financial disclosure by Mexican corporations. The Accounting Review, 3, 533-541.

CICA. (2002). Management's discussion and analysis: Guidance on preparation and disclosure. Canadian Institute of Chartered Accountants.

Clarkson, P. M., Kao, J. L., \& Richardson, G. D. (1994). The voluntary inclusion of forecasts in the MD\&A section of annual reports. Contemporary Accounting Research, 11(1), 423-450. http//dx.doi.org/10.1111/j.1911-3846.1994.tb00450.x

Cooke, T. E. (1989). Disclosure in the Corporate Annual Report of Swedish Companies. Accounting \& Business Research, 19(74), 113-122. http//dx.doi.org/10.1080/00014788.1989.9728841

Cooke, T. E. (1991). An assessment of voluntary disclosure in the annual reports of Japanese corporations. International Journal of Accounting, 26(3), 174-189.

Cooke, T. E. (1992). The impact of size, stock market listing, and industry type on disclosure in the annual reports of Japanese listed corporations. Accounting \& Business Research, 22(87), 229-237. http//dx.doi.org/10.1080/00014788.1992.9729440

Cooke, T. E. (1998). Regression analysis in accounting disclosure studies. Accounting and Business Research, 28(3), 209-224. http//dx.doi.org/10.1080/00014788.1998.9728910

Cunningham, S., \& Gadenne, D. (2003). Do corporations perceive mandatory publication of pollution information for key stakeholders as a legitimacy threat? Journal of Environmental Assessment Policy and Management, 5(4), 523-549. http//dx.doi.org/10.1142/S1464333203001474

Debrency, R., Gray, G., \& Rahman, A. (2002). The determinants of Internet financial reporting. Journal of Accounting and Public Policy, 21(4/5), 371-394.

Donnelly, R., \& Mulcahy, M. (2008). Board Structure, Ownership, and Voluntary Disclosure in Ireland.

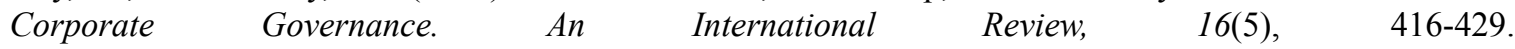
http//dx.doi.org/10.1111/j.1467-8683.2008.00692.x

Ettredge, M., Richardson, V., \& Scholz, S. (2002). Dissemination of information for investors at corporate web sites. Journal of Accounting and Public Policy, 21(Winter), 357-369.

FASB. (2001). Steering Committee Report. Business Reporting Research Project, Improving Business Reporting: Insights into Enhancing Voluntary Disclosure.

Firth, M. (1979). The impact of size, stock market listing, and auditors on voluntary disclosure in corporate annual reports. Accounting \& Business Research, 9, 273-280.

Frankel, R., McNichols, M., \& Wilson, P. (1995). Discretionary disclosure and external financing. The Accounting Review, 70, 135-150. Retrieved from http://www.jstor.org/stable/248392

Gao, S. S., Heravi, S., \& Xiao, J. Z. (2005). Determinants of corporate social and environmental reporting in Hong Kong: a research note. Accounting Forum, 29(2), 233-242. http://dx.doi.org/10.1016/j.accfor.2005.01.002

Gujarati, D. (2006). Essentials of Econometrics. New York: McGraw Hill.

Hackston, D., \& Milne, M. J. (1996). Some determinants of social and environmental disclosures in New Zeland 
companies. Accounting, Auditing \& Accountability Journal, $\quad 9(1), \quad 77-108$. http//dx.doi.org/10.1108/09513579610109987

Harte, G., \& Owen, D. (1991). Environmental disclosure in the annual reports of British companies: A research note. Accounting, Auditing \& Accountability Journal, 4(3), 51-61. http//dx.doi.org/10.1108/09513579110144442

Hassan, O., Giorgioni, G., \& Romilly, P. (2006). The extent of financial disclosure and its determinants in an emerging capital market: the case of Egypt. International Journal of Accounting, Auditing and Performance Evaluation, 3(1), 41-67.

Hossain, H., \& Hammami, M. (2009). Voluntary disclosure in the annual report of an emerging country: the case of Qatar. Advances in Accounting, 25(2), 255-265. http://dx.doi.org/10.1016/j.adiac.2009.08.002

Hossain, M., Ahmed, K., \& Godfrey, J. M. (2005). Investment Opportunity Set and Voluntary Disclosure of Perspective Information: A Simultaneous Equations Approach. Journal of Business Finance \& Accounting, 32(5/6), 871-907. http://dx.doi.org/10.1111/j.0306-686X.2005.00616.x

Hossain, M., Perera, M. H. B., \& Rahman, A. R. (1995). Voluntary disclosure in the annual reports of New Zeland companies. Journal of International Financial Management \& Accounting, 6(1), 69-87. http://dx.doi.org/10.1111/j.1467-646X.1995.tb00050.x

Hossain, M., Tan, L. M., \& Adams, M. (1994). Voluntary disclosure in an emerging capital market: some empirical evidence from companies listed on the Kuala Lumpur stock exchange. International Journal of Accounting, 29(3), 334-351.

Hussainey, K. (2004). A study of the ability of (partially) automated disclosure scores to explain the information content of annual report narratives for future earnings. ( $\mathrm{PhD}$ thesis). Manchester University, Manchester.

Hussainey, K., Schleicher, T., \& Walker, M. (2003). Undertaking large-scale disclosure studies when AIMR-FAF ratings are not available: the case of prices leading earnings. Accounting Business Research, 33(4), $275-294$. http://dx.doi.org/10.1080/00014788.2003.9729654

IASB. (2010). IFRS Practice Statement Management Commentary: A framework for presentation.

ICAEW. (2003). New reporting models for business, London: Institute of Chartered Accountants in England and Wales.

Jaggi, B., \& Low, P. Y. (2000). Impact of Culture, Market Forces, and Legal System on Financial Disclosures. International Journal of Accounting, 35(4), 495-519. http://dx.doi.org/10.1016/S0020-7063(00)00076-5

Jensen, M., \& Meckling, W. (1976). Theory of the Firm: Managerial Behavior, Agency Costs and Ownership $\begin{array}{lllll}\text { Structure. Journal of } & \text { Financial } & \text { Economics, } & 305-360 .\end{array}$ http://dx.doi.org/10.1016/0304-405X(76)90026-X

Kabalski, P. (2012). The IASB's Management Commentary and Modern Paradigms of Management. International Journal of Business and Management, 7(6), 90-98. http://dx.doi.org/10.5539/ijbm.v7n6p90

Kent, P., \& Ung, K. (2003). Voluntary Disclosure of Forward-looking Earnings Information in Australia. Australian Journal of Management, 28(3), 273-285. http://dx.doi.org/10.1177/031289620302800303

Kieso, D. E., \& Weygandt, J. J. (1995). Intermediate Accounting (8th ed.). New York, NY: Wiley.

Krippendorff, K. (1980). Content analysis: An introduction to its methodology. London: Sage Publications.

Lang, M., \& ve Lundholm, R. (1996). Corporate disclosure policy and analysis behavior. The Accounting Review, 71(October), 467-492.

Leventis, S., \& Weetman, P. (2004). Voluntary disclosure in an emerging capital market: some evidence from the Athens Stock Exchange. Advances of International Accounting, 17, 227-250. http://dx.doi.org/10.1016/S0897-3660(04)17001-3

Lim, S., Matolcsy, Z., \& Chow, D. (2007). The association between Board Composition and Different Types of Voluntary Disclosure. European Accounting Review, 16(3), 555-583. http://dx.doi.org/10.1080/09638180701507155

Malone, D., Fries, C., \& Jones, T. (1993). An empirical investigation of the extent of corporate financial disclosure in the oil and gas industry. Journal of Accounting, Auditing \& Finance, 8(3), 249-273. http://dx.doi.org/10.1177/0148558X9300800306 
Marston, C. (2003). Financial reporting on the internet by leading Japanese companies. Corporate Communication: an International Journal, 8(1), 23-34. http://dx.doi.org/10.1108/13563280310458894

Marston, C. L. (1991). The use of disclosure indices in accounting research: A review article. The British Accounting Review, 23(3), 195-210. http://dx.doi.org/10.1016/0890-8389(91)90080-L

Marston, C., \& Polei, A. (2004). Corporate reporting on the internet by German companies. International Journal of Accounting Information System, 5(3), 285-311.

Meek, G., Gray, S., \& Roberts, C. (1995). Factors influencing voluntary annual report disclosures by US, UK and continental European multinational corporations. Journal of International Business Studies, 26(3), 555-572. Retrieved from http://www.jstor.org/stable/155561

Menicucci, E. (2012). La relazione sulla gestione nel reporting delle imprese. Un percorso di lettura e di indagine ispirato dai Principi IAS/IFRS. FrancoAngeli, Milano.

O’Sullivan, M., Percy, M., \& Stewart, J. (2008). Australian Evidence on Corporate Governance Attributes and their Association with Forward-looking Information in the Annual Report. Journal of Management and Governance, 12(1), 5-35. http://dx.doi.org/10.1007/s10997-007-9039-0

Oyelere, P., Laswad, F., \& Fisher, R. (2003). Determinants of Internet Financial Reporting by New Zeland Companies. Journal of International Financial Management \& Accounting, 14(1), 26-63. http://dx.doi.org/10.1111/1467-646X.00089

Patton, J., \& Zelenka, I. (1997). An empirical analysis of the determinants of the extent of disclosure in annual reports of joint stock companies in Czech Republic. European Accounting Review, 6(4), 605-631. http://dx.doi.org/10.1080/09638189700000003

Prencipe, A. (2004). Proprietary Costs and Determinants of Voluntary Segment Disclosure: Evidence from Italian Listed Companies. European Accounting Review, 13(2), 319-340. http://dx.doi.org/10.1080/0963818042000204742

Quagli, A. (2008). Comunicare il futuro. L'informativa economico-finanziaria di tipo previsionale delle società quotate italiane. FrancoAngeli, Milano.

Raffournier, B. (1995). The determinants of voluntary financial disclosure by Swiss listed companies. European Accounting Review, 4(2), 261-280. http://dx.doi.org/10.1080/09638189500000016

Singhvi, S. (1968). Characteristics and implications of inadequate disclosure: a case study of India. International Journal of Accounting, 3(2), 29-43.

Singhvi, S., \& Desai, H. B. (1971). An empirical analysis of the quality of corporate financial disclosure. The Accounting Review, 3(2), 29-43. http://www.jstor.org/stable/243894

Skinner, D. (1994). Why Firms Voluntarily Disclose Bad News. Journal of Accounting Research, 32(1), 36-60.

Smith, C. W., \& Warner, J. B. (1979). On Financial contracting: An analysis of Bonds Covenants. Journal of Financial Economics, 7(2), 117-161. http://dx.doi.org/10.1016/0304-405X(79)90011-4

Tasker, S. C. (1998). Bridging the information gap: quarterly conference calls as medium for voluntary disclosure. Review of Accounting Studies, 3, 137-167. http://dx.doi.org/10.1023/A:1009684502135

Vanstraelen, A., Zarzeki, M. T., \& Robb, S. W. G. (2003). Corporate Nonfinancial Disclosure Analyst Forecast Ability across Three European Countries. Journal of International Financial Management \& Accounting, 14(3), 249-278. http://dx.doi.org/10.1111/1467-646X.00098

Walker, M., \& Tsalta, A. (2001). Corporate financial disclosure and analyst forecasting activity: preliminary evidence for the UK. ACCA Research Report, No. 67.

Wallace, R. S. O., \& Naser, K. (1995). Firm-specific determinants of comprehensiveness of mandatory disclosure in the corporate annual reports of firms listed on the stock exchange of Hong Kong. Journal of Accounting and Public Policy, 14(4), 311-368. http://dx.doi.org/10.1016/0278-4254(95)00042-9

Wallace, R. S. O., Naser, K., \& Mora, A. (1994). The relationship between the comprehensiveness of corporate annual reports and firm characteristics in Spain. Accounting and Business Research, 25(97), 41-53. http://dx.doi.org/10.1080/00014788.1994.9729927

Wang, K. O. S., \& Claiborne, M. C. (2008). Determinants and consequences of voluntary disclosure in an emerging market: Evidence from China. Journal of International Accounting, Auditing and Taxation, 17(1), 14-30. 
Watts, R. (1977). Corporate Financial Statements: A Product of the Market and Political Process. Australian Journal of Management, 2, 53-75. http://dx.doi.org/10.1177/031289627700200104

Weber, R. P. (1985). Basic content analysis (2nd ed.). Newbury Park: Sage Publications.

Zarzeski, M. T. (1996). Spontaneous harmonization effects of culture and market forces on accounting disclosure practices. Accounting Horizons, 10(1), 18-38.

Zoccarato, C. (2012). La Relazione sulla gestione e il Management Commentary. Un'analisi empirica alla luce dei recenti indirizzi internazionali. Esculapio, Bologna.

\section{Note}

Note 1. To develop and test the Disclosure Index the basic step were: define the recording unit (word); define the categories; test coding of a sample of text; assess reliability (the variables generated from the coding represent what we intended it to represent); revise coding rules in order to code all the text in the same way; repeat test coding and revising until reliability is satisfactory; assess achieved reliability. 